\title{
Pelatihan Aplikasi Google Classroom sebagai Alternatif Media Pembelajaran Daring pada TPQ Darul Hikmah Depok
}

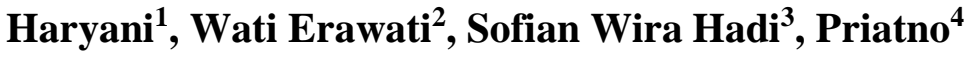 \\ 1,2,3,4 Universitas Bina Sarana Informatika \\ Jalan Kramat Raya No.98 Jakarta, Indonesia \\ e-mail: ${ }^{1}$ haryani.hyi@ bsi.ac.id, ${ }^{2}$ wati.wti@bsi.ac.id, ${ }^{3}$ sofian.sod@bsi.ac.id, \\ ${ }^{4}$ priatno.prn@bsi.ac.id
}

\begin{abstract}
Abstrak
Penelitian ini bertujuan memberikan pelatihan kepada guru-guru TPQ Darul Hikmah tentang penggunaan aplikasi google classroom untuk pembelajaran daring di masa pandemi Covid-19. Permasalahan yang dihadapi para TPQ Darul Hikmah belum dapat melaksanakan pembelajaran jarak jauh atau dalam jaringan (Daring) karena keterbatasan para pengajar dan orang tua siswa dalam pemanfaaatan Teknologi Informasi. Kebutuhan pokok TPQ Darul Hikmah adalah pemanfaatan Teknologi Informasi untuk pembelajaran jarak jauh yang menarik minat belajar para siswa. Solusi untuk mengatasi permasalahan yang dihadapi TPQ Darul Hikmah adalah memberikan pelatihan pemanfaatan google classroom sebagai media pembelajaran daring di masa pandemi covid-19. Metode Pelaksanaan kegiatan pengabdian masyarakat di TPQ Darul Hikmah dalam bentuk pemanfaatan google classroom untuk tenaga pengajar. Pelaksanaan pelatihan secara jarak jauh menggunakan media conference dengan materi yang telah disusun sistematis. Hasil yang diperoleh dari kegiatan PKM ini adalah keterampilan pengajar TPQ Darul Hikmah dalam memanfaatkan google classroom di masa pandemi meningkat menjadi $80 \%$. Target luaran berupa publikasi di jurnal ilmiah cetak atau elektronik, artikel di media masa cetak atau elektronik, video kegiatan dan peningkatan keterampilan pengurus dan pengajar TPQ Darul Hikmah dalam pemanfaatan teknologi informasi untuk pembelajaran jarak jauh.
\end{abstract}

Kata kunci : aplikasi, google classroom, pelatihan, pembelajaran daring, pandemi.

\section{Abstract}

This study aims to provide training to Darul Hikmah TPQ teachers on the use of the Google Classroom application for online learning during the Covid-19 pandemic. The problems faced by Darul Hikmah TPQ have not been able to carry out distance learning or online because of the limitations of teachers and parents in utilixing information technology. The basic need of $T P Q$ Darul Hikmah is the use of information technology for distance learning that attracts students interest in learning. The solution to overcome the problems faced by TPQ Darul Hikmah is to provide training on the use of Google Classroom as an online learning medium during the Covid-19 Pandemic. Methodes of implementing community service activities at TPQ Darul Hikmah in the form of using google classroom for teaching staff. Implementation of training remotely using media conference with material that has been arranged systematically. The results obtained from this PKM activity are the skills of TPQ Darul Hikmah teachers in 
utilizing google classroom during the pandemic increased to $80 \%$. The output targets are publications in printed or electronic scientifc journals, articles in print or electronic mass media, video activities and improving the skill of TPQ Darul Hikmah administrators and teachers in the use of information technology for distance learning.

Keywords:

\section{Pendahuluan}

Pemberlakuan Pembatasan Kegiatan Masyarakat (PPKM) yang diberlakukan pemerintah bertujuan untuk membendung laju kenaikan angka positif virus corona atau Covid-19. Pemerintah mengeluarkan peraturan mengenai pembatasan kegiatan masyarakat selama pandemi virus corona (Corona Virus Deseas) saat ini berdampak terhadap kegiatan sosial yang sangat besar bagi kehidupan masyarakat pada umumnya(Junaidi \& Yani, 2021). Kebijakankebijakan yang diberlakukan salah satunya pada bidang pendidikan yaitu sekolah. Pendidikan merupakan peran penting dalam pembangunan suatu Negara karena pendidikan dianggap sebagai salah satu cara untuk membangun dan membentuk sumber daya manusia yang berkualitas sehingga mampu menciptakan pembangunan nasional yang maju (Salamah, 2020). Dalam proses pembelajaran guru dan siswa dituntut untuk merubah cara pengajaran dan pembelajaran dengan pembelajaran jarak jauh dengan memanfaatkan media digital. Belajar merupakan proses seseorang untuk memahami, mengetahui, dan dapat melakukan dari hal yang tadinya belum dipahami, diketahui, dan tidak dapat dilakukan (Nirfayanti \& Nurbaeti, 2019). Dalam proses belajar mengajar harus saling berinteraksi antara komponen-komponen yang terdapat di dalam proses pembelajaran dalam rangka mencapai tujuan pembelajaran (Wana et al., 2017). Di tengah kondisi pandemi Covid-19 ini proses pembelajaran harus terus berlangsung dengan memanfaatkan bantuan teknologi yang canggih sehingga guru dan siswa dapat mengajar dan belajar sesuai dengan materi pelajaran secara interaktif, produktif, efektif, inspiratif dan menyenangkan. Selain itu guru dan murid menjadi terbiasa dan mahir dalam penggunaan teknologi informasi.

Dalam bidang pendidikan pemanfaatan teknologi informasi untuk proses pembelajaran salah satunya adalah e-learning. E-Learning merupakan Aplikasi yang dapat dimanfaatkan sebagai media pembelajaran melalui internet, untuk memberikan serangkaian solusi untuk meningkatkan pengetahuan dan keterampilan (Sabran \& Sabara, 2019). Pemanfaatan aplikasi e-Learning yang yang saat ini sangat mudah didapatkan yaitu aplikasi google classroom. Google merupakan platform yang sudah familiar di masyarakat yang memiliki banyak fungsi, memberikan kemudahan bagi para penggunanya untuk mendapatkan berbagai macam informasi yang dibutuhkan. (El Fauziah et al., 2019). Aplikasi Google Classroom membantu guru untuk memberikan materi-materi, tugas-tugas dengan efektif dan efesien dan memberikan umpan balik kepada siswa secara langsung, dan dapat berkomunikasi dengan siswa.

Permasalahan yang dihadapi para TPQ Darul Hikmah belum dapat melaksanakan pembelajaran jarak jauh atau dalam jaringan (daring) karena keterbatasan para pengajar dan orang tua siswa dalam pemanfaaatan Teknologi Informasi. Kebutuhan pokok TPQ Darul Hikmah adalah pemanfaatan Teknologi Informasi untuk pembelajaran jarak jauh yang menarik minat belajar para siswa. Solusi untuk mengatasi permasalahan yang dihadapi TPQ Darul Hikmah adalah memberikan pelatihan pemanfaatan google classroom sebagai media pembelajaran daring di masa pandemi covid-19. 


\section{Metode}

Pengabdian Masyarakat ini dilaksanakan dengan menggunakan One Day Workshop yaitu dengan memberikan ceramah dan pelatihan dan metode ini dapat memberikan kesempatan kepada para peserta untuk secara langsung mempraktekkan terhadap teori-teori yang diberikan oleh tutor.

Berikut rangkaian kegiatan pengabdian masyarakat yang dilaksanakan pada Mitra Pengabdian Masyarakat yaitu TPQ Darul Hikmah:

1. Observasi

Obeservasi dilakukan dengan mendatangi secara langsung ke mitra yaitu kepala TPQ Darul Hikmah untuk mengetahui kebutuhan mitra dalam kegiatan pengabdian masyarakat yang akan dilakukan oleh Dosen dan mahasiswa Universitas Bina Sarana Informatika. Setelah mengetahui kebutuhan mitra pengabdian masyarakat maka dosen membentuk tim pengabdian masyarakat sebagai hasil survei lolasi mitra.

2. Wawancara

Wawancara secara langsung dilakukan kepada Kepala TPQ Darul Hikmah dengan menanyakan kebutuhan mitra yang nantikan akan dijadikan objek dalam kegiatan pengabdian masyarakat.

3. Studi Pustaka

Metode studi pustaka ini dengan mempelajari teori-teori yang terkait dengan tema pengabdian masyarakat, dokumentasi mitra dan mencari informasi di internet tentang kondisi terkini dari mitra.

Setelah melakukan metode pengumpulan data di atas maka tim PKM merangkai keterkaitan antara kegiatan yang dilakukan antara tim dengan mitra sebagai berikut:

1. Tim PKM melakukan analisis kebutuhan ke mitra PKM yaitu TPQ Darul Hikmah.

2. Tim dosen membuat hasil analisis kebutuhan dengan merancang kebutuhan pelatihan.

3. Tim dosen membuat modul pelatihan yang akan digunakan sebagai panduan bagi peserta pelatihan.

4. Tim dosen melakukan persiapan untuk pelaksanaan pelatihan.

5. Tim dosen melaksanakan pelatihan dan melakukan evaluasi kepada peserta pelatihan dengan memberikan latihan.

\section{Hasil dan Pembahasan}

Tahap pertama dalam kegiatan pengabdian masyarakat ini adalah dengan mengunjungi mitra pengabdian masyarakat yaitu TPQ Darul Hikmah. Tim dosen bertemu dengan kepala TPQ Darul Hikmah dengan mewawancarai kebutuhan mitra dalam pengabdian masyarakat ini dan pengajuan proposal kegiatan pengabdian masyarakat sebagai syarat administratif. Hal yang diwawancarai terkait dengan penggunaan aplikasi google classroom di masa pandemi ini. Pada tahap pertama ini pun dilakukan survei terkait dengan penggunaan aplikasi google classroom. Berikut hasil survei yang dilakukan oleh tim dosen:

Tabel 1. Survei Tahap Awal

\begin{tabular}{llc}
\hline No & \multicolumn{1}{c}{ Indikator } & Hasil \\
\hline 1 & Kemampuan mengenal aplikasi google classroom & $45 \%$ \\
2 & $\begin{array}{l}\text { Kemampuan mengelola tugas siswa dengan aplikasi google } \\
\text { classroom }\end{array}$ & $25 \%$ \\
3 & Kemampuan mengelola materi dengan aplikasi google classroom & $25 \%$ \\
\hline
\end{tabular}




\section{ABDITEKNIKA}

Jurnal Pengabdian Kepada Masyarakat

Volume 1 Nomor 2 Oktober 2021

ISSN 2775-1694

Tahap kedua menyiapkan modul pelatihan dan slide presentasi. Selanjutnya tim dosen mengunjungi tempat mitra dan menyiapkan kebutuhan presentasi dan dokumentasi yaitu menyiapkan LCD Proyektor, Spanduk Kegiatan Pengabdian Masyarakat serta souvenir untuk peserta pengabdian masyarakat.

Tahap ketiga yaitu pemaparan materi yang disampaikan oleh tim tutor diawali dengan penyampaian materi pembelajaran secara luring dan daring serta pemaparan tentang aplikasi google classroom, cara memberikan materi pelajaran, dan memberikan tugas-tugas di dalam google classroom serta kendala-kendala teknis dalam penggunaan google classroom.

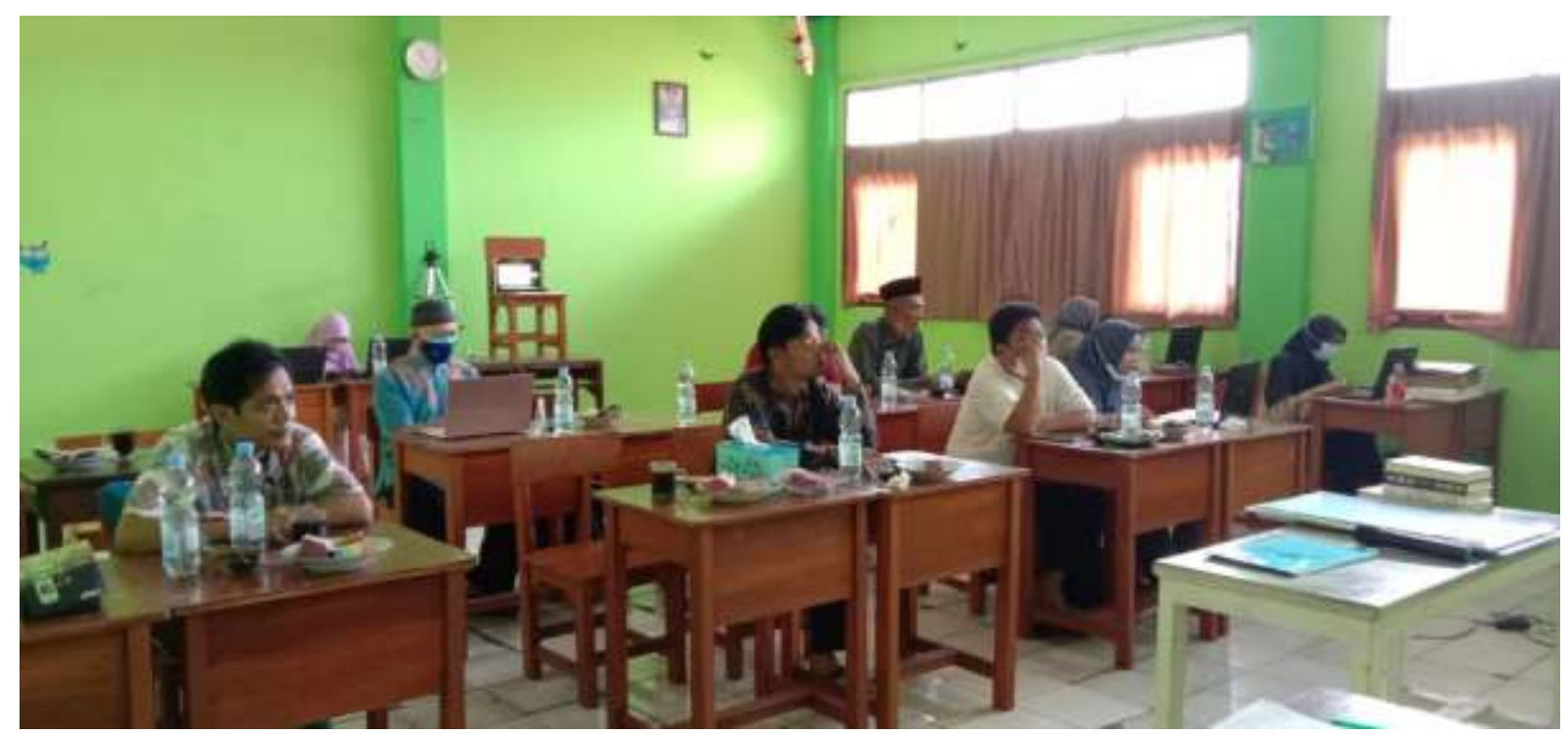

Gambar 1. Suasana Pelatihan Aplikasi Google Classroom

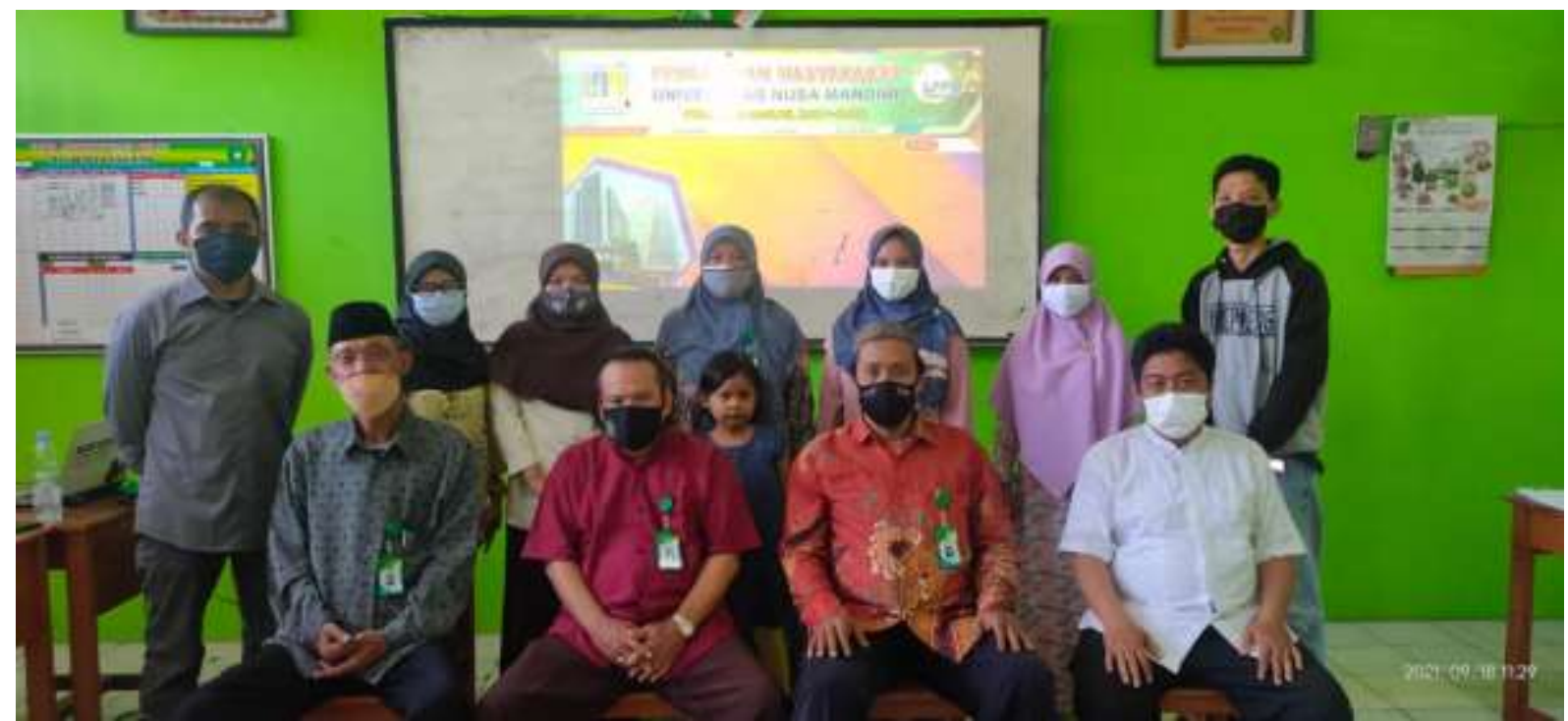

Gambar 2. Sesi Foto Bersama Peserta dan Tim Dosen

Pembelajaran secara daring ini dilakukan karena kondisi pandemi Covid-19 yang masih melanda seluruh dunia. Hal inilah yang membawa pembelajaran luring menjadi daring harus dilaksanakan. Pada awal peralihan pembelajaran guru-guru TPQ Darul Hikmah untuk melakukan koordinasi pembelajaran, memberikan tugas siswa dan menerima hasil tugas 
melalui aplikasi whatsapp. Namun dengan menggunakan sistem ini mengalami beberapa kendala seperti kurang jelasnya hasil tulisan siswa, membutuhkan waktu yang cukup lama untuk men-download tugas siswa. Dengan melihat kondisi tersebut, maka tim dosen pengabdian masyarakat untuk memberikan pelatihan aplikasi penggunaan google classroom dan mulai mengoperasikan pembuatan google classroom. Paparan materi disampaikan satu persatu dan langkah-langkah dalam penggunaan google classroom. Beberapa tim dosen mendampingi peserta yang mengalami kendala dalam mengoperasikan aplikasi google classroom.

Hasil pelaksanaan kegiatan Pengabdian Masyarakat pada TPQ Darul Hikmah Depok yang dicapai melalui pemanfaatan google classroom sebagai media pembelajaran daring di masa pandemi covid-19 yaitu guru dapat memahami dan mengetahui aplikasi google classroom dan mengetahui cara penggunaannya. Meningkatnya pemahaman tentang aplikasi google classroom dan memanfaatkannya untuk kegiatan mengajar secara daring pada TPQ Darul Hikmah. Peserta mampu mengelola kelas pada google classroom untuk mengajar. Dalam kegiatan pengabdian masyarakat ini mitra memfasilitasi ruangan untuk kegiatan pelatihan ketua Yayasan pun menyambut dengan baik dalam kegiatan pengabdian masyarakat.

Adapun hasil peningkatan pelaksanaan kegiatan pengabdian masyarakat pada TPQ Darul Hikmah Depok ini dapat dilihat pada table berikut:

Tabel 1. Hasil Kuesioner Pelaksanaan Pelatihan Google Classroom

\begin{tabular}{cllc}
\hline No & \multicolumn{1}{c}{ Indikator } & \multicolumn{1}{c}{ Hasil } & Keterangan \\
\hline 1 & Materi yang diberikan tepat atau & $95 \%$ menjawab baik sekali. & Diterima \\
& sesuai dengan kebutuhan. & $65 \%$ menjawab baik & \\
2 & Cara pengampaian materi dari tutor ke & $83 \%$ menjawab baik sekali. & Diterima \\
& peserta. & $17 \%$ menjawab baik. & \\
3 & Waktu atau durasi pelaksanaan & $85 \%$ menjawab cukup. & Diterima \\
& kegiatan & $15 \%$ menjawab baik. & \\
4 & Mengetahui cara mengoperasikan & $80 \%$ menjawab ya. & Diterima \\
& google classroom setelah & $20 \%$ menjawab mungkin & \\
& mengikuti kegiatan ini & & \\
\hline
\end{tabular}

Sumber: Hasil Survei tahun 2021

\section{Kesimpulan}

Berdasarkan hasil kegiatan pengabdian masyarakat yang diselenggarakan pada TPQ Darul Hikmah dapat disimpulkan bahwa kegiatan ini sangat baik dan para guru sangat tertarik dengan ilmu pengetahuan yang disampaikan oleh para tutor tentang penggunaan Google Classroom sebagai sarana pembelajaran jarak jauh pada masa pandemi Covid-19. Berdasarkan hasil kuesioner yang diberikan oleh peserta pengabdian masyarakat maka sebesar $85 \%$ peserta dapat menggunakan aplikasi Google Classroom. Dengan demikian kegiatan ini dapat diterima oleh peserta pengabdian masyarakat.

\section{Daftar Pustaka}

El Fauziah, U. N., Suryani, L., \& Syahrizal, T. (2019). Penerapan Google Classroom Dalam Pembelajaran Bahasa Inggris Kepada Guru-Guru Bahasa Inggris Smp Di Subang. 
Abdimas Siliwangi, 2(2), 183. https://doi.org/10.22460/as.v2i2p183-191.3281

Junaidi, A., \& Yani, A. (2021). Sosialisasi Adaptasi Kebiasaan Baru di Masa Pandemi Covid19 Untuk Ibu-Ibu PKK Kelurahan Gembor, Tangerang. Jurnal Pengabdian Kepada Masyarakat, 1. http://jurnal.bsi.ac.id/index.php/abditeknika

Nirfayanti, N., \& Nurbaeti, N. (2019). Pengaruh Media Pembelajaran Google Classroom Dalam Pembelajaran Analisis Real Terhadap Motivasi Belajar Mahasiswa. Proximal Jurnal Penelitian Matematika Dan Pendidikan Matematika, 2(1), 50-59. https://ejournal.my.id/proximal/article/view/211

Sabran, \& Sabara, E. (2019). Keefektifan Google Classroom sebagai media pembelajaran. Prosiding Seminar Nasional Lembaga Penelitian Universitas Negeri Makasar, 122-125. https://webcache.googleusercontent.com/search?q=cache:SS_jKM_r2TAJ:https://ojs.un m.ac.id/semnaslemlit/article/download/8256/4767+\&cd=2\&hl=id\&ct=clnk\&gl=id

Salamah, W. (2020). Deskripsi Penggunaan Aplikasi Google Classroom dalam Proses Pembelajaran. Jurnal Penelitian Dan Pengembangan Pendidikan, 4(3), 533-538.

Wana, P. R., Pangestu, W. T., \& Agustina, D. A. (2017). Perbandingan Prestasi Belajar Matematika Siswa Dengan Menggunakan Metode Pembelajaran Mind Mapping Dan Direct Instruction Pada Siswa Kelas V Sdn Jiwan 01 Madiun. Trihayu: Jurnal Pendidikan Ke-SD-An, 3(2), 83-88. http://jurnal.ustjogja.ac.id/index.php/trihayu/article/view/837 